Fecha de recepción: diciembre 2010

Fecha de aceptación: julio 2011

Versión final: marzo 2012

\section{Fusión de instantes}

Alejandra Niedermaier *

Resumen: Se tratará de establecer cuan "consanguíneas" son las imágenes resultantes de la fotografía, el cine y el video. A partir de este concepto se estudiará a la fotografía como el componente molecular que habita en los lenguajes mencionados. Para ahondar en la íntima relación de éstos se ejemplificará con tres trabajos autorales que presentan distintos modos de enunciación.

Palabras clave: Cine - elemento cero - encuadre - Fotografía - fusión - Video.

[Resúmenes en inglés y portugués en la página 223]

(*) Fotógrafa, docente e investigadora. Maestría en Lenguajes Artísticos Combinados (IUNA, tesis en curso). Se desempeña como docente en la Universidad de Palermo y en el Posgrado de Lenguajes Artísticos Combinados del IUNA. Coordinadora y docente en la carrera de la Escuela de Fotografía Motivarte.

"En el interior de cada fotografía también está el comienzo de una historia que empieza con 'Érase una vez ...” Cada fotografía es el primer fotograma de una película. (Wim Wenders)

A partir de este título, del nombre de "Vasos comunicantes" del apartado y bajo la influencia de la denominación "Alquimia de lenguajes" de todo el cuaderno, se tratará de establecer, a continuación, cuan "consanguíneas"1 son las imágenes resultantes de la fotografía, el cine y el video. A partir de este concepto se estudiará a la fotografía como el componente molecular que habita en los lenguajes mencionados. ${ }^{2}$

Se tratará de realizar una primer aproximación sobre esta íntima relación, a través de distintos ejemplos autorales que anidan en las tres formas de enunciación. Para completar de dilucidar la especificidad propia que cada lenguaje también conlleva quedan pendientes exploraciones sobre la inmanencia, los aspectos comunicacionales, temporales y las relaciones continente/contenido. Raymond Bellour menciona la necesidad de “(...) dibujar las líneas de fuga de un universo de fusión” (Bellour, 2009, p. 9). En un intento de establecer esas líneas de fuga, se puede comenzar caracterizando que la fotografía y el cine surgen, inicialmente y entre otros requerimientos, como una búsqueda de representación. Theodor Adorno opinaba al respecto: 
El proceso fotográfico del film, principalmente representacional, confiere al objeto una significación intrínseca mayor (...) que la otorgada por las técnicas estéticas autónomas. (...) Incluso cuando el film disuelve y modifica sus objetos tanto como le es posible, la desintegración nunca es completa. En consecuencia, nos habilita una construcción absoluta: sus elementos, por más abstractos que sean, siempre conservan algo representacional; nunca son valores puramente estéticos (Oubiña, 2009, p. 108).

Al mismo tiempo, fotografía y cine nacen con un apego a la noción de mímesis, es decir a una premisa de realismo. En el devenir hacia la contemporaneidad estos dispositivos se van desembarazando de estos presupuestos, a pesar de que esta noción continúa subyacente en los dos. Ambos lenguajes son indiciales ${ }^{3}$, es decir, imprimen la huella del referente sobre la película fotográfica o cinematográfica. La tecnología digital, al traducir la información visual en un sistema numérico, rompe con esta indicialidad y posibilita que los signos se transmitan y se combinen de modos diferentes.

Asimismo la detención de la imagen cinematográfica la devuelve inmediatamente a su base fotogramática, fragmentos discontinuos constituidos por espacio y tiempo por una máquina y que son fusionados por otra. Comparten asimismo una especificidad particular: su posibilidad de reproductibilidad técnica. ${ }^{4}$

Jean Louis Comolli considera que el cine es bastardo de la pintura por vía de la fotografía (Comolli, 2007, p. 137). De este modo, está reconociendo que el cine, al que se le agrega el video, están condicionados por la luz (elemento intrínseco del componente fotográfico) en tanto que proyecta haces y sombras que cubren y descubren.

Además de partir del mismo componente molecular, nos encontramos ante gramáticas constructoras de semiosis. Es por eso que Robert Frank (1924), un importante fotógrafo que realizó la serie denominada The Americans, filmó algunas películas a partir del año 1959 como Pull my Daisy (junto a Jack Kerouac y Allen Ginsberg del movimiento beat) entre otras, y dio muestras en toda su obra de una poética reflexiva sobre el tiempo y de una exaltación del gesto autoral. Desde ese punto de vista, escribió su deseo de realizar una película en la que pudiese mezclar su vida privada y su trabajo fotográfico, un "foto film" para: "establecer un diálogo entre el movimiento de la cámara y el congelado de la imagen fija, entre el presente y el pasado, el interior y el exterior, el adelante y el detrás." 5

Como éste, existen varios ejemplos de fotógrafos que realizaron películas y de directores de cine que han hecho fotos. Para todos ellos, ambos dispositivos se encuentran estrechamente vinculados. Agnès Varda y Stanley Kubrick comenzaron sus carreras como fotógrafos. Leni Riefenstahl, Carlos Saura, David Lynch, Abbas Kiarostami, Peter Greenaway y Wim Wenders son algunos ejemplos de realizadores que completan sus búsquedas a través de la foto. Es interesante observar que Kiarostami entabla el tema de las rutas desde la fotografía, el cine y la poesía entremezclando el concepto de ruta con su descomposición en grafismos abstractos. Crea, de este modo, una combinación de expresiones que culminan en una fusión de regímenes.

Chris Marker por su parte, entabla su discurso cinematográfico con la deliberada elección de utilizar reiteradamente la fotografía fija, especialmente en La Jetée cuyo análisis se realiza en los próximos renglones. Es interesante reparar en que tanto él como Agnès Varda se ocupan desde la foto y el cine de la memoria, de los recuerdos, de cómo las imágenes viabilizan la 
comprensión de la estructura que subyace en distintos acontecimientos, de cómo reflejan una construcción simbólica de sentido que opera sobre el imaginario.

Julio Cortázar ayuda a comprender las diferencias gramaticales de ambos lenguajes al trazar una analogía entre la fotografía y el cuento y la novela y el cine. Explica que los fotógrafos y los cuentistas "se ven precisados a escoger y limitar una imagen o un acontecimiento que sean significativos, (...) que operen en el espectador o en el lector como una especie de apertura" 6 donde tiempo y espacio se ven condensados. En ambos casos, la necesidad de eliminar transiciones intermedias (propias de la novela y del cine) obliga a una síntesis y a la creación inmediata de una "atmósfera" y "tensión", como lo indicara el escritor.

En este sentido, es interesante el caso de la serie Film Stills de la fotógrafa Cindy Sherman. En este proyecto, a través de distintas imágenes fijas, ella crea una situación cinematográfica en cada una. Temáticamente y a partir de una puesta en escena particular, Sherman realiza el procedimiento inverso al de la historia del cine: por medio de escenas cinematográficas Sherman retorna a la imagen fija.

Duane Michals constituye otro caso particular ya que en sus Foto secuencias incorpora, a través de varias fotografías, una narratividad. Se destaca entre ellas un grupo de siete imágenes denominado Alice's mirror y otro de nueve denominado Things are queer. Reconoce que necesita un antes y un después para expandir el concepto. Surge entonces una interesante cuestión planteada por Michel Foucault:

Si Duane Michals apeló tantas veces a las secuencias, no es porque vea en ellas una forma capaz de reconciliar lo instantáneo de la fotografía con la continuidad del tiempo para contar una historia. Es más bien para mostrar, por medio de la fotografía que si bien el tiempo y la experiencia juegan siempre juntos, no pertenecen al mismo mundo. $\mathrm{Y}$ el tiempo bien puede aportar sus cambios, el envejecimiento, la muerte, pero el pensamiento-emoción es más fuerte que él; este pensamiento y sólo para él, puede dejar ver sus invisibles arrugas (Foucault, 1982). ${ }^{7}$

Reaparece así nuevamente la capacidad de síntesis de la fotografía planteada por Julio Cortázar. Esta doble pregnancia de ambos lenguajes se puede observar también en el reciente road trip que durante 70 días realizara David Lynch en su Interview project, en el que entrevista a distintas personas tras recorrer 30 mil kilómetros de suelo norteamericano. El encuadre responde a una clara decisión fotográfica ya que aporta información sobre la vida del entrevistado. Esta visita del equipo de Lynch quiere dar cuenta del hombre y su contexto tal como en algún momento lo hiciera el fotógrafo Paul Strand a partir de 1930.8

El componente molecular aparece en las tres gramáticas a través de la mirada, es decir, de la selección de la mirada, de la elección (encuadre) y la validación (edición/montaje/edición) de la misma. El encuadre como primer recurso de restricción de la información. El ojo mira, la cámara se encarga de almacenar lo que el ojo mira. El acontecimiento ya no está en su lugar de origen, está resguardado a través de la mirada en la cámara. El gesto del encuadre incluye el riesgo, el riesgo de mostrarle al otro nuestra subjetiva visión del suceso. Así, el concepto de marco conlleva la decisión de incluir o excluir una porción de la realidad. En ocasiones, resulta importante atender en nuestro análisis no sólo lo presente en la imagen, sino también lo ausente ${ }^{9}$, lo que se 
considera el interjuego encuadre / desencuadre, el riesgo de elegir los espacios in y off, el campo y el fuera de campo.

Phillippe Dubois menciona que las maquinas y sus respectivas tekné pueden convertirse en máquinas de captación (cámara oscura), operadores de inscripción (fotografía), visualización (cine), trasmisión (televisión) y de concepción (tecnologías digitales)(Dubois, 2000).

A partir de la aparición de los medios tecnológicos (entre los que se encuentra el video) se observa una imagen que se constituye con un cierto distanciamiento porque ya no se trata de una inscripción fotoquímica en donde un cuerpo es registrado en tiempo real ante una máquina que se encuentra en el mismo lugar.

El mismo autor considera que existen lazos entre el video y el cubismo (Dubois, 2004, p. 6) ya que ambos, en términos de percepción, instauraron nuevos espacios plásticos. ${ }^{10} \mathrm{Tal}$ vez porque el video da cuenta tanto de lo pensado, imaginado y concebido como del objeto que hace ver. En la concepción de Hamaca Paraguaya de Paz Encina la pregnancia del componente molecular resulta fácilmente apreciable. Pascal Bonitzer alude a que un film es una sucesión de escenas, secuencias ordenadas metódicamente en tomas y planos (Bonitzer, 2007). El video, al nutrirse de lo pensado, lo imaginado y del diálogo "entre" distintos momentos temporales, espaciales y visuales ${ }^{11}$ utiliza en ese sentido las tomas y los planos. En este video se intuyen espacios, sucesos que van más allá del delimitado por los bordes de lo grabado. De algún modo, es como si la significación de la película estuviese dada por ambos espacios, el que registra esa cámara fija puesta sobre un trípode (a través de un plano general) y el off, el fuera de campo jugando, de esta manera, con una cierta inestabilidad espacial. Por otra parte, no hay sincronismo entre los tiempos de la imagen y los tiempos del sonido, lo cual le otorga una sensación de atemporalidad. Una ralentización cumple la función de permitirle a cada sentimiento el tiempo necesario para su total expresión. Su estética se completa con un tono azulino.

El video es, entonces, "objeto" y "acto" (Dubois, 2004, p. 3) al mismo tiempo, en virtud de que los procesos y los modos de circulación forman parte de este dispositivo. Dubois lo coloca entre el orden del arte y el orden de la comunicación, estableciendo así una esfera artística y una mediática. Desde la recepción, su sintaxis lo lleva a pertenecer a la esfera privada mientras que su carácter de proceso y de acción pragmática lo remite a la pública. La mezcla entre lo público y lo privado se halla en el video mencionado, ya que relata la historia de un matrimonio que espera el retorno del hijo que marchó a la guerra del Chaco. ${ }^{12}$ Una especie de agobio particular del matrimonio se traslada a la situación histórica propiamente dicha y a las condiciones climáticas de ese mismo país.

Los tres abordajes que a continuación se analizan en detalle han sido seleccionados por la notoria presencia del componente molecular fotográfico que habita en ellos. En virtud de tratarse del fundamento del intercambio de las particularidades de cada dispositivo, ejerce sobre el receptor un dominio, un sortilegio. 


\section{La Jetée, un modo de fundir instantes}

La Jetée es una película del director, guionista y fotógrafo Chris Marker (1921) realizada en el año 1962. Marker pertenecía, en la década del '60, al grupo Rive Gauche, que funcionaba paralelamente a la Nouvelle Vague francesa. Si nos detenemos en la famosa frase de Jean Luc Godard: "No es una imagen justa, es justo una imagen", en La Jetée podemos encontrar un contacto entre ambos grupos.

El director francés utiliza en esta película un conjunto de imágenes fijas para relatar un experimento científico, un viaje en el tiempo tras un hecho mundial traumático (una figurada tercer guerra mundial). Para mostrar este viaje, Marker realiza una búsqueda y un juego por encontrar imágenes encerradas en esta doble vía de la frase de Godard, a través de una cámara Pentax. ${ }^{13}$

$\mathrm{Al}$ considerar el argumento del film, se observa que este se inserta en un marco futurista propio del género de la ciencia ficción, ya que los captores del personaje central intentan salvar el presente a través de un viaje de su prisionero hacia el pasado y hacia el futuro. Una vez cumplimentada la tarea, él mismo solicita retornar al pasado. "Esta es la historia de un hombre marcado por una imagen de la niñez" relata en los primeros minutos de la película una voz en off. En ese viaje suceden recortes de tiempo y espacio que llevan a encuentros y reencuentros, algunos deseados, otros inesperados y poco inteligibles al principio, pero cuyo desenlace es, de algún modo, un retorno vislumbrado.

La mitología griega narra que Mnemosine, como madre de las nueve musas que patrocinan las artes y las ciencias, es la poseedora de la memoria. Una memoria que fluye en las cercanías de la fuente del olvido representado por la diosa Lete, ligada a Morfeo y a Hipnos, dioses del sueño y de la hipnosis. La película bebe de ambas diosas. Se observan así múltiples formas de rememoración, como por ejemplo cuando reconstruye la ausencia de la protagonista femenina y aparecen rupturas, abandonos y también transformaciones. El museo como morada de lo que Mnemosine recuerda y concibe, se hace visible y audible cuando aparecen ruinas y "en ese museo que sólo está en su memoria". ${ }^{14} \mathrm{El}$ concepto de museo aparece en reiteradas ocasiones: las esculturas, los monumentos, las ruinas y cuando ambos protagonistas visitan el museo de ciencias naturales.

Desde el punto de vista perceptual, soñar vivamente equivale a crear. El cerebro es una energía que se encuentra en una alerta perceptiva, un acto creador capaz de relacionar y transformar. La pregunta aquí sería si, a través de sus ensoñaciones, el protagonista busca modificar su destino trazado o si busca su cumplimiento. Por otro lado, podríamos entrever también un modo de enunciar el carácter onírico que subyace en el lenguaje cinematográfico al librar vértigos imaginarios.

El sufrimiento de a ratos, el goce en otros, conforman un continuo encuentro doliente con la memoria y permiten vincular esta película con Doce Monos (1995) de Terry Gilliam, (basada directamente en La Jetée) y también con Solaris (1972) de Andrei Tarkovski y con Memento (2000) de Christopher Nolan. En todos estos films aparece cierto desconsuelo y consternación como consecuencia de ese ir y venir temporal. Se encuentran rompecabezas donde no aparece clara la conexión entre causa y efecto; y se aprecia, también, un cierto caos perturbador que interroga sobre lo que existe y lo que se imagina.

En La Jetée, se puede apreciar asimismo el esfuerzo del protagonista por volver presente lo que 
no está, por representar la ausencia para completarla con objetos del pensamiento llenos de significado real: "Una habitación auténtica, pájaros auténticos, tumbas auténticas, gatos auténticos, tumbas auténticas".

Y de significado simbólico: "A veces vislumbramos / recuperamos un día de felicidad, el rostro de la felicidad". 15

La fotografía, desde su aparición oficial en agosto de 1839, conlleva una connotación de veracidad que se ha ido desplazando, en los últimos años, a una especie de verosimilitud. Muchos autores sostienen que la fotografía nunca fue auténticamente real, sino que estuvo desde un principio basada en formas más o menos ligadas al simulacro. Barthes en su libro La cámara lúcida decía: "La fotografía es una imagen auténticamente demente, barnizada de realidad".

Es por este desplazamiento que aparecen también pares dilemáticos tales como confianza y recelo, confusión y comprensión, persuasión y lucidez. Los mecanismos de desplazamiento son una característica semiótica en la medida en que atañen a la producción de significado. En la construcción de sentido de La Jetée estos pares juegan un rol importante efectuando un movimiento de vaivén.

Por otra parte, la elección de Chris Marker por el lenguaje fotográfico tiene una estrecha relación con un aspecto ontológico de este lenguaje. La fotografía participa de dos mecanismos intensamente trabajados en esta película, el recuerdo y el olvido. El uso de fotografías para comprender distintos sucesos históricos pasados o presentes permite la reconstrucción del encadenamiento de sus distintos antecedentes. La fotografía como huella de un suceso ocurrido adquiere un valor de testigo (el "yo estuve aquî"16 del fotógrafo y de lo fotografiado) y, a su vez, de símbolo. Además, al evocar se activa una simultánea y extraña percepción del aquí y del allá, del entonces y del ahora. Este lenguaje desarrolla, entonces, una memoria que nos ayuda a elaborar una nueva mirada sobre el devenir, que conlleva a la melancolía que plantea Roland Barthes acerca del medio al mencionar en sus textos "esto ha sido" (Barthes, 1982).

Una fotografía preserva un instante del tiempo y, al suspenderlo, favorece su almacenamiento en la memoria, se convierte en el registro de algo que en el momento de su observación está ausente. La fuerza constativa de la foto existe justamente porque se refiere al tiempo y no al objeto. Teóricos como Walter Benjamin 17 o como John Berger (Berger, 2005) hacen alusión a la particularidad de la fotografía de contener al mismo tiempo pasado y futuro al recortar simplemente el presente, en virtud de que la labor de la memoria anula el tiempo. Dubois habla de un efecto de profecía (Dubois, 2004). Ante una fotografía se reconfigura lo sucedido, los mecanismos de la memoria se ponen en marcha. La conmoción surge, también, por la discontinuidad. Discontinuidad utilizada en La Jetée para dar cuenta de los distintos momentos de dolor, sufrimiento y goce por los que el protagonista atraviesa.

Los fundidos junto a la utilización en un fragmento de una cámara cinematográfica relatan el momento de intensa ensoñación y comunión del protagonista con el personaje femenino. En ese instante, el cambio del lenguaje fotográfico al cinematográfico se torna en un elemento discursivo para aumentar el efecto de ensoñación. Una vez que el espectador se ha introducido en el hábitat de la película, habiendo interpretado ciertos indicios, se encuentra con un punto de ruptura de la articulación establecida: una única secuencia en movimiento, luego de sucesivos y fundidos primeros planos y planos detalle, la protagonista femenina mueve los párpados. Este es el único momento filmado con una cámara de cine. En ese sentido, además de la intensa trama, encontramos cierta interrogación autoreferencial a los dos lenguajes que nos ocupan: 
el fotográfico y el cinematográfico. Esta interrogación se resuelve, de algún modo, a través del énfasis en una operación absolutamente significante del cine como es el montaje.

Para Immanuel Kant, la estructura espacio/tiempo se conforma en el pensamiento humano para relacionarse con el mundo. El gesto de obturar convierte simbólicamente al instante fotográfico en eternidad y es como un acto de apropiación de todos los instantes.

Este acto de apropiación implica la posibilidad de repetir la vivencia del suceso a través de la observación de la fotografía. Así, estas variables de espacio y de tiempo, atributos inherentes a este lenguaje, se convierten en componentes de la memoria.

La representación de un objeto en primer plano o parcialmente (plano detalle) puede convertirse en un signo tendiente a fetichizar o a atraer una fobia. Ambas cualidades aparecen en $L a$ Jetée. Fobia al líder del campamento, fobia al loco con sus ojos grandes y desmesurados; y, en contraposición, los close up de ella, que la inscriben como objeto de consuelo, de amor y, fundamentalmente, de vida. Los planos detalle de esculturas, por ejemplo, se prefiguran también como elementos de construcción de sentido. De este modo, Chris Marker utiliza los conceptos de Eisenstein sobre las posibilidades intelectuales y psicológicas que ofrece el plano detalle.

Se observa también un interesante manejo de la profundidad de campo, por ejemplo, cuando el protagonista se despierta del traslado al futuro y observa al líder del campamento fuera de foco pero claramente perceptible por el espacio intermedio de los parches para los ojos.

Desde el aspecto formal comunicacional, esta película requiere un cierto esfuerzo por parte del receptor ya que pone en juego sus competencias lingüísticas. ¿Se trata de una película filmada o de un montaje de fotos fijas? El receptor requiere, entonces, de una tekné, un saber. Junto a la intriga argumental, el espectador estará pendiente entonces de su puesta en escena.

Otro procedimiento que se utiliza para introducirnos en la trama memorística es el sonido. En esta fotonovela (como lo denomina el mismo Chris Marker) a la voz relatora en off se le superponen, de a ratos, las voces de los guardias en idioma alemán (como ratificación de un estereotipo). En su construcción de sentido, se escucha también una música coral mientras se observan ruinas, melodías que acompañan distintos momentos y, además, sonidos de aeropuerto, de botas militares, de pulsaciones como un modo de marcar una permanente sensación de inquietud e incertidumbre.

El argumento de los experimentadores para retener al protagonista es la necesidad de salvar el presente. Podríamos pensar entonces que el entramado visual y sonoro de La Jetée interroga acerca de un lapso de tiempo sin recuerdos y sin planes ya que "no hay forma de eludir el tiempo."18 En ese sentido, el uso de las imágenes fotográficas se torna en un verdadero “operador de inscripción" (Dubois, 2000).

Se cumplen así en este film los "entre-tiempo de la imagen fija y de la imagen movimiento" mencionados por Bellour (Bellour, 2009).

\section{Cruce de lenguajes y de culturas: Shirin Neshat}

Esta artista iraní nacida en Qazvin en 1957 entabla sus enunciaciones a través de un uso simultáneo de distintos lenguajes, utilizando las diferentes disciplinas como herramienta de activismo y compromiso. Este entramado político está vinculado con la cultura de su país, con sus derroteros político-sociales como así también con la problemática del género femenino y la 
carencia de poder de autodeterminación en el orden colectivo. 19

Radicada desde los diecisiete años en Estados Unidos (1974), vive actualmente en New York y trabaja con frecuencia en Turquía y Marruecos y últimamente en Laos.

Su obra está compuesta por fotografías, videos y video-instalaciones que encuentran una gran acogida en distintos museos del mundo.

Tras doce años de ausencia hace su primer visita a Irán en 1990. El impacto que le produce este viaje motiva no sólo regulares visitas a ese país, sino todo un discurso referido a los debates transculturales y a los procesos de identidad y representación.

La revolución iraní que abolió la dictadura secular del régimen Pahlavi y llevó al poder a la teocracia de la República Islámica de Irán coincidió con el proceso de globalización, el final de la guerra fría y el advenimiento del posmodernismo en Occidente. Además del clima político imperante, el país se encontraba recuperándose de una larga guerra contra Irak

Dos de sus principales series de fotografías son desarrolladas entre 1993 y 1997. Una de ellas se denomina Women of Allah y muestra imágenes de una violencia explícita, con mujeres que enarbolan armas.

En Turbulent (video de 1998) divide la acción en dos pantallas simultáneas. En la primera, un hombre oficia un acto religioso ante otros hombres aunque les da la espalda y canta hacia el espectador. En la segunda, la silueta de una mujer le da la espalda al espectador y se encuentra delante de un auditorio vacío. Se escuchan ambas voces simultáneamente. En determinado momento, él termina de cantar, se vuelve a los hombres del público y agradece el aplauso. Luego, recomienza el canto, dándoles la espalda y mirando al espectador del video. Paulatinamente, primero de costado, se comienza a ver la cara de ella, hasta que finalmente ambos miran al espectador. En ese movimiento, empieza a escucharse la voz de la mujer y ya no la del hombre. El fondo (sala vacía) va desapareciendo también y ella canta sobre un fondo negro. Mientras que la pantalla de él continúa estática, y mientras se escucha un sostenido lamento por parte de ella, todo el fondo gira y alterna entre el fondo negro y la sala vacía.

A partir de la lentitud en la organización de la imagen en las fotografías mencionadas y en este video, se aprecia un doble énfasis en el componente molecular y en la ceremonia como integrante de una especie de rito. El sonido (ambos cantos y el lamento posterior cuyo volumen va incrementándose) opera también como un integrante fundamental de esta video-instalación performática. Neshat apela en varias ocasiones a la emisión de sonidos y cantos provenientes de su propia voz. En este video, sin embargo, se trata de Sussan Deihim, cantante contemporánea iraní. Es ella la que aparece en el video y canta. Todo esto alude también a la prohibición en Irán de que las mujeres canten en público.

En Zarin (2005) se visualiza una joven prostituta y a hombres que tienen borrados sus rasgos. Este video integra luego el largometraje Women without men que recibiera en el 2009 el premio León de plata en el Festival de cine de Venecia y que narra la historia de cinco mujeres iraníes en el año 1953 durante un golpe de Estado que fuera apoyado por potencias extranjeras. Como una pincelada de lo acontecido, el relato se configura a través de una prostituta, una maestra, dos muchachas y una mujer de mediana edad de clase media. Está basado en una novela del autor iraní Shahrnush Parsipur del mismo título.

Su última obra, Juegos del deseo, es una video-instalación ambientada en Laos. En este caso, los dos protagonistas de ambos sexos (cada uno en una pantalla) se miran frente a frente. Captura también a los que asisten a la performance de ambos. Aquí, Shirin, a través de distintos retratos 
fotográficos de distintos personajes, enlaza las realidades de Laos con las de Irán. Muestra así distintos acontecimientos que encierran algunos "secretos" arribando, de este modo, a un conocimiento acompañado por un cierto carácter mágico-religioso.

Su obra se caracteriza por un permanente juego de tensiones, donde se percibe una fusión entre la función emotiva y la función poética. Además se registra una explícita búsqueda de la función fática ya que en muchas de sus imágenes podemos observar un uso absolutamente conciente de formas que hacen referencia a círculos sagrados y rituales, de líneas oblicuas que operan de visibles separadores entre géneros. En Fervor apela a una mujer y a un hombre que se encuentran en la intersección de un camino, proyectando sombras y diagonales donde lo que se aprecia es la imposibilidad de un punto de encuentro. Estas formas operan como verdaderos significantes. Desde el punto de vista de la percepción, traza así un mapa cognitivo en función de dos fuentes de expectativas: lo culturalmente aprendido sobre las formas y como éstas, a su vez, operan como facilitadoras de la visión y la comprensión.

La elección del blanco y negro en muchas de las fotografías también aporta un sentido de énfasis, de contrastes, de dramatismo. En los videos, ya sean en color o en blanco y negro, la aparición de sombras, de densidades dan cuenta de un entramado simbólico que significa la presencia de una permanente amenaza.

Desde el punto de vista semiológico, los ritos, las costumbres a las que hace referencia en las imágenes operan como signos que conforman el modo de enunciación de Neshat. Así las escrituras iraníes en las manos, los cuerpos y el iris de los ojos crean una relación de metatextualidad. ${ }^{20}$ De este modo, Shirin considera el cuerpo humano como un territorio pasible de enunciaciones, un territorio que remite directamente a sus condiciones históricas y sociales, convirtiéndose así en un lugar donde se pueden redefinir las identidades colectivas. La mano como elemento metonímico del "hacer" ha mantenido en el tiempo su carácter simbólico. Al que deben adicionarse otros: afecto, solidaridad, gesto anafórico (Kristeva, 1981, pp. 121-125). Al respecto, Deleuze y Guattari manifestaron que: "El cuerpo lleno no representa nada del todo. Por el contrario, son las razas y las culturas las que designan regiones sobre este cuerpo, es decir, zonas de intensidades, campos potenciales. (...)"(Deleuze y Guattari, 1995, p. 91).

Tanto en las fotografías como en los videos se cumpliría con la característica descripta por Richard Schechner como "conducta restaurada" (Schechner, 2000) ya que los mismos evidencian un contenido performatico en virtud de que hacen alusión a gestos, rituales y conductas propios de su país y que, además, el espectador percibe fácilmente como una conducta. Marvin Carlson caracteriza la oposición a una cultura inmodificable como un rasgo performático. Toda la obra de Shirin Neshat demuestra una constante oposición a lo establecido por la cultura de su país. La performatividad es siempre la reiteración de un conjunto de normas y, en la medida en que se convierte en acto en el presente, disimula su condición de repetición. Es así como estas situaciones performáticas no sólo representan los conflictos sociales sino que los muestran, los presentan. Para lograr este objetivo entonces, lo que se vislumbra en sus trabajos es una esmerada búsqueda de unión entre dramatismo y estética. Elabora de este modo una conducta nueva, relacionada metafóricamente con su antecesora "cruda" 21 , a efectos de dilucidar los distintos dilemas. La función simbólica se encuentra presente en esta especie de rituales mostrando así el subyacente mito fundante. Mitos y costumbres que a través de estas conductas se buscan modificar.

En sus obras Shirin demuestra un manejo anacrónico del tiempo. En términos de Georges Didi 
Huberman: "Ante una imagen -tan reciente, tan contemporánea como sea-, el pasado no cesa nunca de reconfigurarse, dado que esta imagen sólo deviene pensable en una construcción de la memoria, cuando no de la obsesión" (Didi Huberman, 2006, p. 12).

Justamente, Neshat muestra en sus imágenes su obsesión, una obsesión histórica, social, cultural y de género a través de un anacronismo que utiliza una multiplicidad de temporalidades. Es en ese anacronismo, por otra parte, que ella actualiza la memoria y convoca a la conformación de imaginarios individuales y sociales. En su modo de ritualizar el mito (todo lo que parece sagrado en Irán) aparece su deseo de confrontación. Conforma un lenguaje en donde las imágenes se convierten en verdaderos "síntomas" y presentan una problemática. Al respecto, Georges Didi Huberman expresa: "Lo que la imagen síntoma interrumpe no es otra cosa que el curso normal de la representación” (Didi Huberman, 2006, p. 44).

De este modo, en su pasaje de la foto al video, del video al cine, ella utiliza los distintos dispositivos visuales como un modo de reflexión. Tal vez sea por eso que en todos ellos encontremos un componente fotográfico omnipresente, como una manera de asentar esa introspección.

Shirin Neshat se constituye así en una productora integral, no sólo por el cruce de lenguajes que se manifiesta en el entramado de su obra, sino por el claro abanico de contenidos que se trasluce en sus acciones; acciones que apuntan a la renovación de conductas míticas muy instaladas en su cultura.

\section{Tecnología y sinestesia narrativa: Soft Cinema}

La elección de Soft Cinema de Lev Manovich y Andreas Kratky se debe a que las imágenes de los tres videos que habitan en este proyecto resultan sumamente sugestivas en virtud de su componente fotográfico (Bellour, 2009, p. 325) ${ }^{22}$. En los tres clips que integran este proyecto (Absences, Mission to Earth y Texas) se aúnan el cruce de lenguajes, aspectos perceptivos y visuales. Aparecen así imágenes cuya inestabilidad remite a las vibraciones del pensamiento puestas en escena por Jacques Rancière denominado como "fraternidad de metáforas" (Rancière, 2010, p. 125). La imagen electrónica, pasible de composiciones y descomposiciones trasgrede, relativiza la noción de realidad. El layout simétrico de toda la estructura de Soft Cinema remite al gusto de Lev Manovich por las pinturas de Piet Mondrian y a cierta estética televisiva. Desde el punto de vista tecnológico explora tres aspectos:

- Algoritmo: la creación de un software diseñado por los autores que controla la cantidad de ventanas que contendrá la pantalla. Asimismo, selecciona de distintos videos, por medio de palabras clave, la temática, locación, movimiento de cámara y colores, entre otras características. La división de la pantalla en ventanas posee antecedentes cinematográficos ${ }^{23}$ y proviene, asimismo, de videos científicos.

- Base de datos: esta base contiene varios videos, animaciónes 2D, dibujos animados, escenas $3 \mathrm{D}$, diagramas, mapas, sonidos, música, texto y variables narrativas.

- La creación de otra base de datos destinada a visualizar el proyecto de diferentes modos.

Se podría decir que la intención de Manovich y Kratky es establecer sus videos como una obra abierta en segundo grado ya que buscan constantemente introducir "nuevas posibilidades de una forma" (Eco, 1992, p. 80). Es por esto que se puede percibir cierta imprevisibilidad en los mismos, especialmente en Absences. Se observa así una continua dinámica en su construcción. 
$\mathrm{Al}$ respecto, Umberto Eco plantea:

Desde las estructuras que se mueven hasta aquellas en que nosotros nos movemos, la poética contemporánea nos propone una gama de formas que apelan a la movilidad de las perspectivas, a la múltiple variedad de las interpretaciones. Pero hemos visto igualmente que ninguna obra de arte es de hecho "cerrada", sino que encierra, en su definición exterior, una infinidad de "lecturas" posibles (Eco, 1992, p. 48).

El mismo autor establece que esta estructura abierta forma parte de un "proyecto comunicativo" (Eco, 1992, p. 59) y que es plasmada a través de elecciones estéticas formales y de sentido de cada productor. Esta intencionalidad es muy notoria en Soft cinema.

Tanto Texas como Mission to Earth toman la memoria, a través de procesos sensoriales, como uno de sus ejes narrativos centrales. De algún modo, en los tres se detecta un énfasis en el recuerdo sinestésico.

En estos dos clips se aprecia un manejo temporo-espacial que, de a ratos, resulta un tanto caótico. En virtud de que en el mundo que se entreve en los tres clips no es tan fácil encontrar un espacio propio y particular, Manovich y Kratky utilizan las mencionadas categorías con el mismo sentido que Mijaíl Bajtín las consideraba con el nombre de cronotopo. 24

Ambos videos tratan de demostrar los aspectos itinerantes del mundo contemporáneo haciendo alusión a la globalización en sus diversas particularidades: lugares, no lugares ${ }^{25}$, marcas (de gaseosas, en el caso de Texas, como elemento de referencia tranquilizador que produce sensación de hogar y pertenencia), entre otros.

Se percibe también todo lo relativo a la migración que toma sustancia a través del encadenamiento de las imágenes y de las voces en off.

En el caso de Mission to Earth, la narrativa adopta aspectos provenientes del cine futurista (propios del género de ciencia ficción). Una película que también parte de este antecedente, y de la cual también encontramos cierta filiación en Soft, es en La Jetée, arriba analizada, en la cual la memoria y sus connotaciones sensoriales resultan pregnantes.

Hallamos así, en la ventana grande, icónicas imágenes que remiten a la realidad cotidiana de la protagonista que proviene de otro planeta y que, ya hace tiempo, había sido enviada a la tierra en una misión que no demuestra tener fin. Mientras que en la ventana más pequeña localizamos imágenes más abstractas plenas de texturas y formas.

Un efecto sinestésico pronunciado se encuentra en una de las primeras imágenes (esta sí en ventana grande) en la cual se puede apreciar "desde adentro" el lavado de un auto en un lavadero automático. Esto es utilizado como si la protagonista se encontrara en su interior (casi como si ella misma fuese el auto), provocando así una especie de imagen háptica 26 . Es, en este momento, que el cruce entre la imagen, la metaimagen, la música y la voz en off masculina que explica los derroteros de esta mujer enviada a una irrevocable misión, consolidan una percepción completa y convocan a una sensación de embriaguez, de éxtasis. 27

El plano y el montaje forman parte de las unidades mínimas del lenguaje cinematográfico. El plano funda la idea de sujeto en cine. Un film encadena imágenes. Esto no ocurre necesariamente en el video. La utilización de los distintos planos y la edición en estas composiciones encuentran nuevos modelos narrativos lindantes con la experimentación. 
La problemática migratoria e itinerante ya mencionada se explica en la siguiente frase emitida por la voz en off “(...) no se hallaría en su antigua morada ni en la nueva en la tierra”. Esta metáfora de este fenómeno tan generalizado en la actualidad también puede remitir a la propia historia de Lev, nacido en Moscú e inmigrante a USA y de carácter absolutamente nómade.

En este clip la pantalla llega a dividirse en tres ventanas.

Texas, por su parte, elabora su narrativa sobre estos mismos aspectos (memoria, recuerdo, lo nómade, lo sensorial, las ciudades) a través de una voz en off femenina. Comienza en el Barrio Chino y encadena su narración mostrando distintos países (Cuba, entre otros), temas varios (delfines, la radiación, por ejemplo). Relata la historia de su madre y padre, de sus orígenes y de distintos derroteros hasta llegar a su presente.

Llega a dividirse hasta en cuatro ventanas y el color junto con cierto tratamiento saturado del mismo resultan un elemento visual y perceptual importante. Los textos se modifican topológicamente, juegan con el tamaño e introducen íconos en su estructura.

Absences presenta una fisura, un pliegue a cierto pensamiento algorítmico estructurado. El encadenamiento de imágenes que se visualiza en este video pauta un quiebre del objeto mismo de la escena. ¿Se trata de una hoja, de un paisaje o se trata de otra cosa totalmente diferente? El plano secuencia torna subjetivo el instante del registro en virtud de que narra desde sí el deambular de un personaje masculino que nunca aparece (a diferencia de los otros dos clips cuyas protagonistas son femeninas y de las cuales uno puede conformarse un rostro).

"He was so lonely and lost in the world" / Se encontraba tan solo y perdido en el mundo, evidencia esta frase que aparece escrita. Este clip no posee voz en off y toda la historia aparece relatada por textos que corren linealmente. El sonido se torna un elemento perceptual eminente, por ejemplo, en el momento en que se escuchan los pasos del protagonista, momento que resume, de algún modo, el contenido de todo el clip. Reitera al igual que en los otros dos videos el tema de los "no lugares". Se puede leer como voz del protagonista "Nobody ask me to stay"/ Nadie me pidió que me quedara.

El encadenamiento de escenas genera continuas nuevas territorialidades y estratos. Siempre en blanco y negro, las transformaciones remiten a un encadenamiento de imágenes de paisajes en la ventana grande y de elementos abstractos en las pequeñas (ocasionalmente se aprecian hasta tres ventanas) que portan la sucesión propia de las películas surrealistas como, por ejemplo, $\mathrm{La}$ Estrella de Mar de Man Ray (1927). Con respecto a los paisajes, primero se muestran imágenes de naturaleza, luego de paisaje urbano, después abstractas y finaliza alternando entre las tres. Manovich cita al psicólogo norteamericano Edward Titchener que aventuraba que (...) "una idea abstracta es una especie de fotomontaje, una imagen mental que es resultado de la sobreimpresión de muchas percepciones o ideas particulares (...)" (Manovich, 2006, p. 107). Si bien en Abscences no se trata de fotomontajes, el encadenamiento de imágenes también nos lo hace percibir como una idea abstracta, como una imagen mental.

Apreciamos en todo el proyecto en su conjunto una jerarquización por igual de las partes y del todo y cómo cada parte está en el todo y el todo se encuentra en cada una. Esta característica es muy visible en los tres videos, ya que la división de la pantalla en ventanas, desde donde desfilan escenas diferentes, implica una ratificación de esa intencionalidad. Otro elemento que conforma este principio es la adopción de un montaje audiovisual basado en el contrapunto musical. Ambos autores reconocen en esta elección una influencia de los principios de montaje elaborados por el cineasta Serguei Eisenstein. 
En este proyecto se encuentran nuevos modelos narrativos lindantes con la investigación y el ensayo. Sobreimpresiones, wipes e incrustaciones forman parte del dispositivo videográfico y lo caracterizan como una tekné donde la tecnología y lo real se encuentran estrechamente vinculados. Las sobreimpresiones y las incrustaciones multiplican el componente molecular y lo convierten en capas combinadas que dan cuenta, por ejemplo, de pensamientos inconcientes, de ensoñaciones, de verdades ocultas.

Se aprecian en Soft fragmentos discontinuos y escalonados, propios de lo que Manovich menciona en su libro sobre los nuevos medios, pudiéndose distinguir dos capas diferenciadas: "la capa cultural" y la "capa informática" (Manovich, 2006, p. 93). La trama, el relato que plantea en ellos y el modo de entablarlo corresponden a la primera, mientras que las distintas variables informáticas que utiliza forman parte de la segunda. La modularidad o la "estructura fractal" de todo Soft Cinema responde a esta variable (Manovich, 2006, p. 75).

¿Podría enmarcarse Soft Cinema como un caso de intertextualidad? Tal vez sí. La intertextualidad es un fenómeno interdisciplinario y recurrente en la posmodernidad. Es un concepto que proviene de la semiótica del discurso expuesto por Julia Kristeva en los '60 y retomado por Umberto Eco y por Roland Barthes. Se trata de textos que circulan en red, que se encuentran conectados, que se relacionan entre sí y que siempre remiten a otros textos, a través de citas, alusiones o reescrituras. Jean Francois Lyotard señala a la posmodernidad como un proyecto de reescritura. Precisamente por eso, la intertextualidad se inscribe como una práctica de este tiempo. Dentro de la intertextualidad se distinguen dos modalidades: aquella donde cada creador plantea su propio punto de vista sobre una obra anterior y que algunos teóricos denominan con vocablos tales como "cita", "remake", "parodia", "trasposición" 28 o "pastiche". En esta modalidad se advierte la idea de traslado, de transplante, de poner algo en otro sitio, de acaparar ciertos modelos pero pensándolos en otro registro o en otro sistema, logrando, al mismo tiempo, inquietar el texto original. La modalidad de la apropiación implica dos sentidos que se superponen y opera articulando elementos existentes, es decir, tomando literales pedazos de una obra que, al colocarlos en otra, dan origen a un proceso de resemantización. Probablemente, el atractivo de ambas modalidades sea la posibilidad de jugar con los paradigmas. En este sentido, poseen efectivamente un carácter lúdico.

Por su parte, Néstor García Canclini entiende por hibridación procesos que existían en forma separada y que se combinan para generar nuevas estructuras, objetos o prácticas (García Canclini, 2008, p. 14). Para completar esta idea, Nicolás Bourriaud menciona que, para las prácticas artísticas contemporáneas, en lugar de utilizar el concepto de "formas" se debe considerar el más abierto de "formaciones", como oposición a un objeto cerrado (Bourriaud, 2008, p. 22). Manovich y Kratky apoyan toda la estructura del proyecto en elementos traspuestos.

Fernando Tejerizo considera que el net art provoca, desde su aparición, amores y odios de la misma forma que sucediera cuando surgió el video arte. Al mismo tiempo, integra de algún modo, éste último al primero. A su vez, Manovich plantea que la instalación, el objeto, la performance y el happening (a partir de la década del '60 y retomando lo iniciado por las vanguardias históricas) abrieron el camino para estas nuevas prácticas en donde la interrelación de los lenguajes, la presentación de la sumatoria de disciplinas de representación junto a otras y la convocatoria a la participación del receptor posibilitaron la aparición del net art (Manovich, 2006, p. 104). Soft Cinema explora dentro del net art y del video arte generando tal vez un nuevo par cronotópico: virtualidad y ficción narrativa. 
Tal vez la parábola de los tres lechos de Platón pueda servir de ordenamiento para el análisis de estas formas estéticas correspondientes a "la nueva imaginación" 29. Manovich y Kratky utilizan, en este proyecto, videos de muchos otros autores elegidos algorítmicamente, conforman una urdimbre a través de una base de datos donde entremezclan distintos elementos visuales junto con elementos musicales y sonoros para crear una ficción narrativa apoyada en una percepción integral. Así como en la mencionada parábola, Platón llega a concluir que no se logra la mimesis, se puede llegar, en este caso, a la conclusión que no hay representación. La representación se ha perdido en todos los pasos descriptos. Nos encontramos así ante una presentación que remite a una lejanía, a un aura apartado del benjaminiano (ya no es irrepetible, entre otras características) y cercano al aura fría que define José Luis Brea, cuando plantea la existencia de una desintensificación del valor aurático. Brea aventura, asimismo, que: "El aura va a ser ya sólo el sentido" (Brea, 1991). De este modo, se puede concebir otro interrogante: ¿podemos hablar de un espesor de sentido propio en el caso de Soft Cinema? Sí, absolutamente. La sucesión y asociación de imágenes producen sentidos incluso, muchos de ellos, fueron descriptos más arriba. ¿Y de una poética propia de Manovich y Kratky? Tal vez también. La duda surge a partir de la extrema utilización intertextual, ya sea por medios tecnológicos o por otros. Estos modos enunciativos solicitan entonces varias y abiertas exploraciones teóricas que, por otro lado, irán modificándose en virtud de la rápida mutabilidad de las formas de articulación estética.

Finalmente, la tecnología aplicada en este proyecto hace de intermediario, de proceso de imágenes, de pasaje del elemento cero.

\section{A modo de conclusión}

En la fotografía, lo instantáneo se convierte en pose, en una pausa del tiempo. Por lo descripto en los casos analizados, si detenemos el movimiento tanto en el cine como en el video, retornaremos a la imagen despojada, ¿Entonces, en esa exploración hacia el interior de cada dispositivo, no surgirá nuevamente el componente molecular fotográfico?

Roland Barthes sostiene que "el fotograma nos entrega el interior del fragmento" (Barthes, 1986, p. 66). Es por eso que, fotogramas y elementos cero, son en definitiva componentes moleculares constructores de fragmentos. A propósito, Mijaíl Bajtín dice que ninguna palabra está deshabitada ya que la conocemos teñida de alguna connotación. Los fragmentos se constituyen así en conformadores de mundos. Agnès Varda, por ejemplo, en la película Las playas de Agnès crea claramente su mundo a través de un entramado que rinde tributo a la consanguinidad, expuesta en el inicio del presente escrito, entre los tres dispositivos visuales.

De este modo, la fotografía, el cine y el video son particularmente propicios para interrogar, problematizar, para introducirse en los pliegues y en las hendiduras de los mundos a fin de contribuir, de este modo, a su inteligibilidad. 


\section{Notas}

1. Concepto tomado de Paul Virilio en relación al tema.

2. Raymond Bellour considera que la foto conforma el fotograma cinematográfico y el elemento cero del video, en Bellour Raymond (2009). Entre Imagenes, foto, cine, video. Buenos Aires: Ediciones Colihue, p. 325. Por su parte, Jean Louis Comolli lo denomina "la unidad discreta del cine" en Comolli Jean Louis, "Documento y espectáculo", conferencia dictada en la Alianza Francesa de Buenos Aires en el año 2007.

3. Conjunto de signos que mantienen una contigüidad física con su referente.

4. Se hace referencia así a lo analizado por Walter Benjamin, en La obra de arte en la época de la reproductibilidad técnica en 1936.

5. En el prefacio del libro J'amerais fair un film Photo Poche, 1983 encontrado en Bellour Raymond, ibid, p.12.

6. Conferencia dictada en La Habana en 1962.

7. Foucault Michel, prefacio del catálogo de la retrospectiva de Duane Michals en el Museo de Arte Moderno de la Ville de Paris en 1982.

8. John Berger en su libro Mirar, sostiene sobre los retratos de Paul Strand (1890-1976), "Yo soy como me estás viendo. (...) El presente del verbo ser se refiere solamente al presente, pero sin embargo, cuando lleva delante el pronombre personal de primera persona, pasa a asimilar el pasado que es inseparable de ese pronombre. Yo soy incluye todo lo que me ha hecho ser de esta forma." Berger agrega que su equivalente cinematográfico serían Flaherty, De Sica y Rossellini en algunas de sus películas (Buenos Aires: Ediciones de la Flor. 2005, pp. 61, 64 y 65).

9. Especialmente en el análisis de fotografías que relatan sobre avatares e imaginarios históricos y sociales.

10. Historiadores de arte como Erwin Panofsky y Pierre Francastel consideran que cada cultura crea su propio espacio plástico.

11. A los que hacía alusión Robert Frank.

12. Enfrentamiento entre Paraguay y Bolivia ocurrido en 1932.

13. La autora de estas líneas siempre elaboró sus imágenes con una cámara Pentax K 1000 y recientemente se ha comprado una cámara digital de la misma marca.

14. Voz en off.

15. Voz en off. Con el sentido expresado más arriba aparecen en la película también esculturas, retratos, paisajes.

16. Se hace referencia aquí a la inscripción que Jan Van Eyck (1390-1441) introduce en su pintura El matrimonio Arnolfini, 1434 (National Gallery).

17. El concepto al que se alude no sólo aparece en Pequeña historia de la fotografía, sino también en Infancia en Berlín hacia 1900 y en Crónica de Berlín.

18. Voz en off de la película

19. Lucy Lippard hace referencia ya en 1983 acerca del arte activista y su utilización de diferentes lenguajes que pueden circular en redes.

20. En el sentido que lo define Gérard Genette en su libro Palimpsestos. La metatextualidad constituye para este autor una de las cinco relaciones transtextuales y se la comprende como la relación que une un texto a otro texto. 
21. Término acuñado por Claude Levi Strauss para trabajar los pares: naturaleza/cultura. En Mitológicas. México: Fondo de Cultura Económica, 1986.

22. Bellour Raymond, op.cit, p. 325 En la nota 2 ya se hizo referencia a que Raymond Bellour caracteriza este componente como el "elemento cero" del video.

23. Peter Greenaway en Escrito en el cuerpo divide la película en dos ventanas en diversos momentos.

24. Mijaíl Bajtín en Teoría de la novela toma este concepto de la teoría de la relatividad de Einstein refiriéndose a las coordenadas espacio-tiempo y a la materialización del tiempo en el espacio en relación a la literatura.

25. Se toma aquí el concepto de Marc Augé sobre los no-lugares en Por una antropología de la movilidad (2007) y en Los no lugares, espacios del anonimato (1998), ambos Barcelona: Editorial Gedisa. 26. La imagen háptica es un elemento significante de discurso ya que une dos modalidades sensoriales, la vista y el tacto. En este tipo de imagen, podemos visualizar, a menudo, verdaderas sinécdoques que convocan el sentido táctil. En cine encontramos un antecedente en los primeros minutos de Hiroshima Mon Amour de Alain Resnais.

27. Conceptos tomados como características de lo dionisíaco de Nietzsche Friedrich (1999) en El nacimiento de la tragedia. Madrid: Alianza, p. 20.

28. Utilizo este término para el lenguaje fotográfico porque creo que, para este medio, es el que mejor designa el fenómeno.

29. Término acuñado por Vilém Flüsser para nombrar al net art.

\section{Lista de Referencias Bibliográficas}

Augé, M. (2007). Por una antropología de la movilidad. Barcelona: Gedisa.

(1998). Los no lugares, espacios del anonimato. Barcelona: Gedisa.

Barthes, R. (1986). Lo obvio y lo obtuso. Barcelona: Paidós Comunicación.

(1982). La cámara lúcida. Barcelona: Gustavo Gili.

Bajtín, M. (1989). Teoría y estética de la novela. Madrid: Taurus.

Bellour, R. (2009). Entre Imágenes: foto, cine y video. Buenos Aires: Colihue Imagen.

Benjamin, W. (1982). La obra de arte en la época de su reproductibilidad técnica en Discursos interrumpidos I. Madrid: Taurus.

Berger, J. (2005). Mirar. Buenos Aires: Ediciones de la Flor.

Bonitzer, P. (2007). "Qué es un plano" en El campo ciego. Ensayos sobre el realismo en el cine. Buenos Aires: Santiago Arcos Editor.

Bourriaud, N. (2008. 2a Ed.). Estética relacional. Buenos Aires: Adriana Hidalgo Editora.

Brea, J. L. (1991). Las auras frías. Barcelona: Editorial Anagrama.

Comolli, J. L. (2007a). "Documento y espectáculo", conferencia dictada en la Alianza Francesa de Buenos Aires.

(2007b). Ver y poder. Buenos Aires: Nueva Librería, Fundación Telefónica.

Deleuze, G. y Guattari, F. (1995). "El Anti Edipo” en Capitalismo y Esquizofrenia. Barcelona: Ed. Paidós.

Didi Huberman, G. (2006). Ante el tiempo. Buenos Aires: Adriana Hidalgo Editora.

Dubois, P. (2004). "Video y teoría de las imágenes, para una estética de la imagen video" en Vi- 
deo, Cine, Godard. Buenos Aires: Libros del Rojas, UBA.

(2001). "De una imagen, del otro o de la influencia del cine en la fotografía creativa contemporánea” en la publicación periódica Exit n³: Imagen y Cultura. Fuera de escena. (2000). "Máquinas de imágenes: una cuestión de línea general" en Video, Cine, Godard. Buenos Aires: Libros del Rojas, UBA.

Eco, U. (Ed. 1992). Obra Abierta. Barcelona: Planeta Agostini.

Foucault, M. (1982). Catálogo de la retrospectiva de Duane Michals en el Museo de Arte Moderno de la Ville de Paris

García Canclini, N. (Ed. 2008). Culturas híbridas. Buenos Aires. Paidós Estado y Sociedad.

Genette, G. (1989). Palimpsestos. La literatura en segundo grado. Madrid: Taurus [1982].

Kristeva, J. (1981) (2da edición). El gesto, ¿práctica o comunicación? en Semiótica 1. Espiral Ensayos, Editorial Fundamento.

Levi Strauss, C. (1986). Mitológicas. México: Fondo de Cultura Económica.

Manovich, L. (2006). El lenguaje de los nuevos medios de comunicación. La imagen en la era digital. Buenos Aires: Paidós.

Nietzsche, F. (1999). El nacimiento de la tragedia. Madrid: Alianza.

Rancière, J. (2010). El espectador emancipado. Buenos Aires: Manantial.

Oubiña, D. (2009). Una juguetería filosófica. Buenos Aires: Manantial.

Rancière, J. (2010). El espectador emancipado. Buenos Aires: Manantial.

Schechner, R. (2000). Performance. Teoría y prácticas interculturales. Buenos Aires: Libros del Rojas.

\section{Bibliografía}

Acha, J., Colombres, A. y Escobar, T. (Ed. 2004). Hacia una teoría americana del arte. Buenos Aires: Ediciones del Sol.

Augé, M. (2007). Por una antropología de la movilidad. Barcelona: Gedisa.

(1998). Los no lugares, espacios del anonimato. Barcelona: Gedisa.

Barthes, R. (1986). Lo obvio y lo obtuso. Barcelona: Paidós Comunicación.

(1982). La cámara lúcida. Barcelona: Gustavo Gili.

Bajtín, M. (1989). Teoría y estética de la novela. Madrid: Taurus.

Bazin, A. (Ed. 1990). “Ontología de la imagen fotográfica” en ¿Qué es el cine? Madrid: Editorial Rialp.

Bellour, R. (2009). Entre Imágenes: foto, cine y video. Buenos Aires: Colihue Imagen.

Benjamin, W. (1982). La obra de arte en la época de su reproductibilidad técnica en Discursos interrumpidos I. Madrid: Taurus.

Berger, J. (2005). Mirar. Buenos Aires: Ediciones de la Flor.

Bonitzer, P. (2007). "Qué es un plano" en El campo ciego. Ensayos sobre el realismo en el cine. Buenos Aires: Santiago Arcos Editor.

Bourriaud, N. (2008. 2a Ed.). Estética relacional. Buenos Aires: Adriana Hidalgo Editora.

Brea, J. L. (1991). Las auras frías. Barcelona: Editorial Anagrama.

Carlson, M. (2001). "Performance" en Anuario Gallego de Estudios Teatrais, Consello da Cultura Galega.

Colombres, A. (2005). Teoría transcultural del arte. Buenos Aires: Ediciones del Sol. 
Comolli, J. L. (2007). Ver y poder. Buenos Aires: Nueva Librería, Fundación Telefónica. (2007). "Documento y espectáculo", conferencia dictada en la Alianza Francesa de Buenos Aires.

Deleuze, G. y Guattari, F. (1995). “El Anti Edipo” en Capitalismo y Esquizofrenia. Barcelona: Ed. Paidós.

Didi Huberman, G. (2006). Ante el tiempo. Buenos Aires: Adriana Hidalgo Editora.

Dubois, P. (2004). "Video y teoría de las imágenes, para una estética de la imagen video" en Video, Cine, Godard. Buenos Aires: Libros del Rojas, UBA.

(2001). "De una imagen, del otro o de la influencia del cine en la fotografía creativa contemporánea" en la publicación periódica Exit n³: Imagen y Cultura. Fuera de escena. (2000). "Máquinas de imágenes: una cuestión de línea general” en Video, Cine, Godard. Buenos Aires: Libros del Rojas, UBA.

Eco, U. (Ed. 1992). Obra Abierta. Barcelona: Planeta Agostini.

Foucault, M. (1982). Catálogo de la retrospectiva de Duane Michals en el Museo de Arte Moderno de la Ville de Paris

García Canclini, N. (Ed. 2008). Culturas híbridas. Buenos Aires. Paidós Estado y Sociedad.

Genette, G. (1989). Palimpsestos. La literatura en segundo grado. Madrid: Taurus [1982].

Jameson, F. (1999). El posmodernismo y la sociedad de consumo en El giro cultural, Manantial.

Kristeva, J. (1981) (2da edición). El gesto, ¿práctica o comunicación? en Semiótica 1. Espiral Ensayos, Editorial Fundamento.

Levi Strauss, C. (1986). Mitológicas. México: Fondo de Cultura Económica.

Manovich, L. (2006). El lenguaje de los nuevos medios de comunicación. La imagen en la era digital. Buenos Aires: Paidós.

Niedermaier, A. Memoria fotográfica del centenario de la Argentina, en AA.VV. Construir Bicentenarios Latinoamericanos, Observatory on Latin America (OLA) de la New School University de New York a ser publicado en el transcurso de 2011.

(2008). Algunas consideraciones sobre la fotografía a través de la cosmovisión de Jorge Luis Borges en AA.VV, Alberto Farina y Alejandra Niedermaier (comp.) Cuaderno 27: Borges y las artes ( $y$ las artes en Borges). Buenos Aires: Universidad de Palermo.

(2007). Desde la docencia y la investigación fotográfica, la trasposición: su devenir/su límite, en AA.VV. Actas de Diseño III. Buenos Aires: Universidad de Palermo.

(2006). Desde la docencia y la investigación: cómo abordar el análisis de la práctica fotográfica actual en AA.VV Actas de Diseño II. Buenos Aires: Universidad de Palermo,.

Nietzsche, F. (1999). El nacimiento de la tragedia. Madrid: Alianza.

Rancière, J. (2010). El espectador emancipado. Buenos Aires: Manantial.

Russo, E. (2000). Cine: una puesta en otra escena en AA.VV. El medio es el diseño. Buenos Aires: Libros del Rojas, Eudeba.

Oubiña, D. (2009). Una juguetería filosófica. Buenos Aires: Manantial.

Rancière, J. (2010). El espectador emancipado. Buenos Aires: Manantial.

Schechner, R. (2000). Performance. Teoría y prácticas interculturales. Buenos Aires: Libros del Rojas. Vernant, J. P. (2008). Atravesar fronteras. México: Fondo de Cultura Económica. 


\section{Recursos Electrónicos}

Entrevista de Arthur Dantho. Disponible en www.bombsite.com/issues/73/articles/2332 Tejerizo, F. El net art: la estética de la red. Disponible en: www.aleph-arts.org/pens/tejerizo.html. www.interviewproject.davidlynch.com

www.softcinema.net

Summary: The author tries to stablish the relationship existing between the resulting images of photography, cinema and video. From this concept photography will be studied as the molecular component that lives in those visual languages. In order to go deep in this intimate link three examples of different authors are given to display the different ways of enunciation

Key words: cinema - element zero - frame - fusion - photography - video.

Resumo: $\mathrm{O}$ escrito procura estabelecer cómo são as relacões entre as imagens resultantes da fotografia, o cinema e o vídeo. A partir deste conceito se estudiará à fotografia como o componente molecular que mora nas lenguagens mencionadas. Para a profundização da íntima relação se apresentam tres exemplos autorales que presentam diferentes maneiras de enunciação.

Palavras chave: cinema - elemento zero - enquadre - fusão - fotografia - vídeo. 